\title{
Nation, Faith and War: The Birth of Freedom in France and the United States
}

\author{
Herman T. Salton ${ }^{1}$ \\ ${ }^{1}$ University of Wales, Department of International Politics, Aberystwyth, UK \\ Correspondence: Herman T. Salton, Department of International Politics, Room 3.25, University of Wales, \\ Penglais Campus, Aberystwyth SY23 3FE, UK. Tel: 44-197-062-1610. E-mail: hes3@aber.ac.uk
}

Received: October 17, 2012 Accepted: November 14, 2012 Online Published: February 26, 2013

doi:10.5539/jpl.v6n1p24

URL: http://dx.doi.org/10.5539/jpl.v6n1p24

\begin{abstract}
Although both France and the United States take pride in the secularism of their legal systems and claim historical primacy when it comes to establishing a human rights regime based on secular laws, their constitutional separation of Church and State was achieved through very different historical circumstances. By comparing the French and US approaches to republicanism and secularism, this article argues that French history is a prime example of the controlling tendency of European nation-states over religion - and that this is precisely what distinguishes it from the United States. The contribution also shows that the connection between laïcité and France's imperialism was intimate, and that this represents a second crucial difference between the French and the American conceptions of secularism.
\end{abstract}

Keywords: United States, republicanism, France, Laïcité, imperialism, church-state separation

\section{Introduction}

The French and American processes of historical separation between Church and State have been pivotal in the development of their legal systems and have inspired several other secular nations throughout the world. The 1789 French Declaration of Human Rights and the 1791 US Bill of Rights are regarded as the philosophical (and secular) basis of international human rights law and are both admired abroad and revered at home with an enthusiasm that borders on devotion. Although the French take pride in their chronological primacy, the Americans retort that the Déclaration remained unapplied for decades as France was engaged in constant conflicts. Interestingly, both countries see themselves as the land of human rights (Chélini-Pont, 2005: 14).

Yet these remarkable legal achievements should not overshadow the fundamental differences between - and the many contradictions of - the religious histories of France and the US. While both countries have produced pioneering secular laws, they were accomplished in very different ways. In France, historically, religion has been associated with the Catholic Church and its entanglement with the State could not have been stronger. Indeed, this partly explains why religious feelings have traditionally been perceived as a threat to the French State. For new-born European nations trying to increase their authority, religion was problematic since it was inherently revolutionary and it offered an "alternative view of public order", as Thomas of Kempis put it (Mastellaro, 1994: 96). By contrast, the US Founding Fathers saw religion as a sign of freedom rather than oppression.

This article compares the role of religion in these two countries. It begins by looking at the ideas of secularism, revolution and republicanism, before delving into the complex and intimate connection between laïcité and French imperialism. The article concludes that the disparate position of religion in France and the United States - and the opposing attitudes towards it — must be situated in, and understood through, the historical processes specific to each country.

\section{Religion, Revolution and Republicanism in America and France}

\subsection{Church-State Separation in America and France}

America and France witnessed varying degrees of entanglement between Church and State, a fact that came as no surprise to Tocqueville, who famously wrote that "[a]longside every religion lies some political opinion which is linked to it by affinity. If the human mind is allowed to follow its own bent, it will regulate political society and the City of God in the same uniform manner and will, I dare say, seek to harmonize earth and heaven" 
(Tocqueville, 2003: 336). A complete separation of Church and State is impossible to achieve in any society, Tocqueville pointed out, for religion can be considered a sui generis form of government.

French history provides one of the most persistent examples of Church-State entanglement, but it should be noted that throughout Europe such a union was the rule rather than the exception. Perhaps the most symbolic illustration of this relationship took place in Saint Peter's Cathedral in Rome on Christmas Eve of 800 AD, when Pope Leo III placed the Roman imperial crown upon the head of Charlemagne as a sign of his gratitude for the latter's efforts in imposing Christianity in Europe. Typical of the future controversial relationship between the institutions they represented, both men thought they were gaining something at the expense of the other: Charlemagne believed that he could claim the Church's holy stamp because he had become the Emperor, and the Pontiff considered himself to be above the Emperor by virtue of the fact that he had crowned him. The Investiture controversy - a vicious row between Papacy and Empire about the right to convey God's will — was soon to develop, resulting in a series of savage religious wars throughout Europe (Stout, 1998: 486). This situation of spiritual and temporal union was only broken in France in 1905, when the strategic alliance with the Catholic Church was severed and the foundations for a new legal system based on religious neutrality were laid.

In America, too, the early days were characterized by union rather than separation. Moreover, it is important to remember that the established churches of the Puritan Fathers entailed vicious forms of religious persecution against people belonging to different faiths. Indeed, the practices of these early churches were almost wholly antithetic to the principles of tolerance and secularism that the Founding Fathers were to enshrine so solemnly in the 1979 Bill of Rights (Note 1). While the tumultuous marriage with the Catholic Church thrived virtually uninterrupted for almost one and a half millennia in France, in America the established churches founded by the English colonies in the $17^{\text {th }}$ century started to collapse after only a century and the separation between the temporal and the spiritual was reached, at least constitutionally, as early as 1791 .

The chronology of the separation is intimately connected with the religious landscape of the two countries. The 'secular' precocity of the new world was not only the consequence of a peculiar interpretation of the new Enlightenment ideas, but it also reflected an extraordinary demographic change-a change that soon resulted in the doubling and re-doubling of the colonies' population and brought an impressive array of different religious groups to America (Note 2). In contrast to the situation in France, where the spiritual landscape had been monopolized by the all-powerful Catholic Church, the demographic diversity soon brought religious diversity to America - and this to such an extent that the established churches eventually found it impossible to resist the competition of the hundreds of different spiritual groups and religious affiliations.

The greatness of the US Founding Fathers was in their timely acknowledgement of these momentous changes and in their conclusion that the separation was not only the best guarantee of good government but also the only viable alternative in a multi-religious America. "[Religious] freedom", Madison wrote, "arises from that multiplicity of sects which pervades America and which is the best and the only security for religious liberty in any society, for where there is such a variety of sects there cannot be a majority of any one sect to suppress and persecute the others" (McConnell, 1990: 1479). You only have to look at the all-pervasive and monopolistic presence of the Catholic Church in France, Madison might well have thought, to understand why a marketplace of religions is crucial (Note 3).

\subsection{Revolution in America and France}

These socio-cultural differences, already momentous at the beginning of the $18^{\text {th }}$ century, were augmented by other, more ideological ones in the revolutionary era of the fin de siècle, a crucial period that exposed the different historical role of religion in the two countries. In the $18^{\text {th }}$ century, the starting point for both America and France was the same: the Enlightenment. Their end point was also the same: revolution. Yet there were a number of crucial differences.

Whereas the French revolutionaries saw religion as conflicting with the Age of Reason, their American counterparts viewed it as its most powerful expression. So while the French confiscated Church property, replaced the Christian calendar with a revolutionary one and substituted Christianity with a civil religion, the Americans believed that reason and revelation were not incompatible. Since religion was the foundation of Republican virtue, they believed that it was possible (indeed, desirable) to be a religious nation without having a religious government.

The result was an 'atheist' revolution in France, in contrast to the deeply religious revolution in America. To put it differently, France used the Enlightenment to revolt against religion (which, due to the Church-State entanglement and Catholic support for the monarchy and aristocracy, was seen as a form of oppression), whereas America, equally inspired by the Enlightenment, revolted in favour of religion (which was perceived as a source 
of freedom) (Safran, 2003: 51). "In America, the fires of revolution were lit by the Puritan preachers of New England and their counterparts throughout the thirteen colonies", one author observed. "By contrast, the fury of the revolution in France was directed against church and synagogue, and in Paris the revolutionaries installed a prostitute upon the altar of Notre Dame Cathedral" (Hutson, 2002: 162).

It should also be noted that the intentions of the French and American revolutionaries were different. In France, the Jacobins wanted to destroy the ancien régime of the Bourbons, whereas in America the aim was to re-establish the previous regime, namely that of Anglo-Saxon liberties. This also explains the fact that the revolutionary style was very different on the two sides of the Atlantic: in America, it consisted of long and sophisticated deliberations with the objective of reaching a broad consensus, while in France it took the far quicker and simpler form of the guillotine.

It is therefore important to note that the two countries, each equipped with the same philosophical basis (the Enlightenment), endowed with the same religious belief (Christianity) and inspired by the same noble purpose (freedom), took two opposing paths leading to strikingly different ends. In a way, this was the big paradox of Christianity. In France, partly because of the role played by aristocracy, religion became a synonym for oppression and abuse - and when the Revolution came, it was ridiculed as mere superstition. In America, thanks to the marketplace of religions, Christianity became a symbol of freedom and pluralism, inspiring both the Revolution and the Founding Fathers (Hutson, 2002: 164).

Why this difference? The answer is perhaps provided by Tocqueville. Keep religion out of state affairs, he suggested, and you will indeed diminish its apparent force while augmenting its real power:

When a religion seeks to base its empire only upon the desire for immortality which torments every human heart equally, it can aspire to universality, but when it happens to combine with a government, it has to adopt maxims which only apply to certain nations. Therefore, by allying itself to a political power, religion increases its authority over some but loses the hope of reigning over all (Tocqueville, 2003: 347).

It is here that European Christianity went tragically wrong: by mingling with worldly affairs, it ended up losing its most precious asset - spirituality — and it became as fragile as those worldly powers. Interestingly for our comparison, this is precisely the point where the great message of both the US and French revolutions is to be found - and where the genius of the Founding Fathers meets that of Tocqueville. The journey was different and France took a further century to pass from the theory (1789) to the practice (1905) of the separation, but the conceptual arrival point was the same and was expressed by Tocqueville in these graphic terms: "I am so deeply convinced of the almost unavoidable dangers which face beliefs when their interpreters meddle in public affairs...that I would sooner chain up the priests in their sanctuaries than allow them to leave them" (Tocqueville, 2003: 634). This is a conclusion that the majority of the Founding Fathers would have wholeheartedly embraced.

\subsection{Republicanism in America and France}

These historical circumstances led to major differences in the foundational underpinnings of the two nations. While the American Republic was the immediate result of the Revolution, the French state - and its union with the Catholic Church — was already several centuries old when the Revolution attempted to modernize it in 1789. As a consequence, while the American Revolution was immediately and uncontroversially identified with the new nation and the constitutional principles enshrined by the Founding Fathers formed the object of a large popular consensus, the same was not true of France.

La République was born out of an exceptionally fierce ideological confrontation between the State and the Catholic Church, and the long and painful process of separation leading up to 1905 kept France constantly on the verge of civil war. Thus, the relatively peaceful beginnings of the US Republic, at least in terms of religion (Bailyn, 2003:136), contrast with the tumultuous and violent birth of the French République (Peña-Ruiz, 2003: 45). The latter's foundational years were characterised by a partisan and intransigent approach; indeed, the very existence of the new-born polity was believed to be under constant threat from an 'internal' and omnipotent enemy that could still mobilize millions of people spiritually, if not physically. "It is necessary for France to kill the Catholic Church if France does not want to be killed by it", Victor Hugo famously told the French Parliament on the eve of the separation (Hugo, 1985: 219).

The awareness of this menace explains why la République was constantly trying to find the best way to prevail over the counter-revolutionary impulses of its enemy, whilst simultaneously trying to establish a consensual constitutional framework. While the US revolution gave birth to the unified and previously non-existent American Nation, the French revolution exposed a momentous fracture, a fracture that could only disappear with 
an increased role for the state and a progressive marginalization of the Catholic Church. This passage from a principe de catholicité to a principe de laïcité would infuse and affect all sectors of society, beginning with education (Bruley, 2004: 113-130).

\subsection{French Gallicanism and Civil Religion}

The confrontation between Church and State in France was by no means limited to the revolutionary era, something that marks a further major difference with the US. The relationship between the French kings and the Catholic Church was hardly festive; indeed, significant tensions emerged very early on as the French kings saw the enormous spiritual and temporal power of the Church as a threat to their own authority. It is not the fact that the conflict existed that makes France unique-European history is a product of that fight—but rather it is the fact that the French kings soon stood up to the Church with remarkable strength. What is special, in other words, is French Gallicanism and its centuries-long attempt to limit the power of the Catholic Church (and thus religion) Indeed, some observers still consider this to be at the core of France's relationship with her religious groups.

This very French political philosophy was to prove lethal to the union of Church and State and it still influences, mutatis mutandis, France's approach to religion today. It emerged as early as in 1297 when Philip the Handsome declared that he "regarded his royal titles as deriving directly from God" (Autrand, 1974: 44); it was confirmed in 1682 when the Declaration of the French Clergy emphasized that "the Pope and the Church only have power over spiritual matters" (Charlier-Dagras, 2002: 18); it received a major boost in 1790 when the Civil Constitution of the Clergy required Catholic priests to take an oath of allegiance to the French state (Note 4); it was strengthened in 1801 when the Emperor required a much more radical oath of allegiance from the clergy; and it was confirmed in 1905 when the French state formally decided not to "recognize any religion" but organised a system of separation which is still characterized by Gallican tendencies (Bruley, 2004: 435). As late as 2000 - and within the context of the creation of the Conseil Français du Culte Musulman (CFCM) - the French state was asking representatives of the Muslim religion to sign a solemn declaration that certified the compatibility of Islam with the laws and values of la République. "The full adhesion...to these principles", the document read, "indicates the willingness to be bound by the legal framework that simultaneously provides for freedom of religion in France and the laïque character of French institutions" (Hafiz and Devers, 2005: 84).

Yet the uniqueness of the French experience - and its most relevant difference with the United States-does not lie in the fact that the French state has historically competed with the Catholic Church for temporal power. Rather, the particularity lies in the fact that this Gallican challenge also soon extended into the arena of 'moral' authority, something that became evident in the years leading up to the birth of the Third Republic at the end of the $19^{\text {th }}$ century. "French laïcité", one author wrote, "is unique precisely because the French state...offered a model of moral enchantment that replaces that of the Catholic Church" (Ormières, 2002: 8). At the end of the $19^{\text {th }}$ century, a popular consensus emerged that la République was incompatible with the Catholic Church —and thus with religion; indeed, a républicain was understood to be a person attached to the French revolution and to its ideals of egalitarianism, free thinking, human rights and primacy of human over religious law—all values that the Catholic Church rejected at the time. In addition, the counter-revolution historically found its principal basis in the pro-aristocratic and pro-monarchic Catholic Church. Consequently, the attachment to the idea of laïcite displayed by supporters of la République became intertwined with a vigorous anti-clericalism and was often hard to distinguish from a broader anti-religious sentiment.

As a result of this climate of confrontation, the word républicain came to identify a person who believes in something higher than France's institutions. "[A] Republican is not only a good citizen as understood by Plutarch or Washington", it was observed, "and not only a supporter of the Republican form of government; he or she must be, in addition, a devout son or daughter of the Revolution, a friend of Freedom, of the People, of the Motherland, an enemy of clericalism - a laïque person, in common parlance" (Agulhon, 1992: 112). This is why terms like République and républicain are not only part of the constitutional jargon in France, but represent the symbols of an ideological struggle that goes well beyond the institutional structure of the State (Scot, 2005: 25). Interestingly, the effects of this very French approach are not limited to a bygone age, but they very much inform contemporary France. Virtually all sides of the French political spectrum nowadays agree that la laïcité - and therefore la République - is a foundational value of the nation. As one author observed, "[l]aïcité is a fundamental principle of Modern [France]. [Yet] there still is, in our French idea of laïcité, something that remains unexpressed and that is an alter-ego of laïcité: republicanism" (Renault and Touraine, 2005: 13). In contrast with the United States, where the separation of Church and State is merely an institutional mechanism without any kind of 'spiritual' underpinning and certainly without any pretension of moral superiority vis-à-vis religion and spirituality, in France la République has historically been identified with la laïcité, which is thought as indissociable from typically French values such as equality and freedom. 
This situation has momentous consequences for the ways in which France and America perceive religion. The purpose of the separation in France was to protect the state from the deleterious effects of the Catholic Church (and therefore religion), while in America the aim of the Founding Fathers was to defend religious freedom from the possible excesses of the state (Brookings, 2004: 9). Historically speaking, therefore, France seems unwilling to acknowledge the existence of a moral authority higher than that of the state, while the United States not only concedes it but actually considers this religiosity to be the very foundation of the Nation. As one author wrote,

the theoretical underpinning of the Free Exercise Clause, best reflected in Madison's writings, is that the claims of the 'universal sovereign' precede the claims of civil society, both in time and in authority, and that when the people vested power in the government over civil affairs, they necessarily reserved their unalienable right to free exercise of religion in accordance with the dictates of conscience (McConnell, 1990: 1512).

This is quite different from the situation in France (Note 6).

\subsection{Religion and Education in America and France}

French schools are the clearest example of - as well as the most crucial place for developing - this 'civic religion' that emerged directly from the Revolution. The separation of Church and State was not possible without a radical 'de-catholicisation' of French schools since "the Revolution did not accept any body, any partial grouping, or any religious faction to mediate between the state, purveyor of freedom, and the individuals who receive this freedom" (Bruley, 2004: 127). For what person would allow his own children to be educated by his adversary? "The mission of Christ's soldiers has in the past been easy", Aristide Briand, the moderate architect of the 1905 law, told Parliament in 1904, "for government has left the [school] doors open to the enemies of the state" (Scot, 2003: 76). These doors were sealed in the 1880s with the passage of legislation that prevented any person belonging to a religious order from teaching in French primary schools. This caused a veritable guerre scolaire, a new religious conflict that once again pitted Church and State against each other, angered the Vatican and served as the precursor to the sharper separation of 1905.

Regarded as a veritable 'education to freedom'-l'école de la liberté-because of its humanistic message of emancipation and intellectual liberation from the dogmas and infallible precepts of the Catholic Church, the French education system soon acquired a symbolic importance. Indeed, French schools came to embody a philosophical and almost mystical idea of knowledge as a journey towards free thinking and enlightened criticism. Yet there was another crucial mission that schools were expected to accomplish: the unification of France after centuries of religious wars and the strengthening of la République vis-à-vis the Catholic Church. Edgar Quinet, in his work about the role of French schools, wrote that ' $[t]$ here must be a place where conciliation, union, peace, civic concord are taught instead of the inexorable conflicts caused by beliefs and churches, and this place is the laïque school" (Quinet, 2001: 43). Indeed, schools soon became the 'sanctuaries' of modern France (Rémond, 2001). To say that they became laïques does not mean that French schools became atheist—quite the contrary. What it does mean, however, is that they have since purveyed a certain idea of human relations that is founded on the revolutionary principles of universality, equality, républicanisme à la française and self-sufficiency of the human mind. It is arguably this universalistic tendency of French education that has managed to unite a previously divided country successfully behind a common cause and which has formed independent-thinking French citizens.

However, critics maintain that this egalitarian attitude also had negative effects, discouraging diversity and anything that could look like 'segregation' ('tendance communautaire'), particularly in the religious arena. As it has been observed and quite apart from any legal consideration,

the Republican ideology ... considers religion as a potential danger, a danger for consciences [and] a danger for the dearly fought right to personal freedom .... Since it is supposed to unite all French people around their République, secularism needs enemies whom it must fight (Garey, 2005: 821).

A civic faith negatively interpreted as a 'release from religion' can hardly be farther-conceptually, historically and philosophically - from the intentions of both the Puritans and the Founding Fathers of the United States (Hutson, 2002: 1-8).

\subsection{Concluding Thoughts on Religion in France and America}

When it comes to their religious histories, the most significant difference between America and France lies with the chronology and with the specific circumstances of the separation. In France, la République was the result of religious fighting and the 1905 law intervened at the end of a long and painful conflict, like an armistice that warring parties slowly came to accept. In America, on the contrary, the First Amendment coincided with the 
birth of the new Republic and was thus associated with the founding project of the nation from the very beginning. Unlike the controversial and violent character of the French laïcité, which was contested by the Catholic Church until well after the First World War, the US constitution is thus relatively uncontroversial and is regarded to be the basic instrument guaranteeing individual rights within the federal state. The result is that while laïcité is seen as a synonym for the unifying character of the République in France, in America secularism only represents a rule of the institutional game, rather than a 'metaphysical' value in itself. To say that the word laïcité possesses a strong anti-Catholic and anti-religious component is, historically speaking, entirely accurate, as religion has been largely associated with violence and oppression in France.

\section{Imperialism, French Assimilationism and US Multiculturalism}

"Imperialism", Hannah Arendt wrote, "[is] the one great crime in which America was never involved" (Arendt, 1959: 33). This was not true of France, whose colonial adventures proved to be a unifying and consensual force throughout the $19^{\text {th }}$ and $20^{\text {th }}$ century. From 1880 to 1900 alone, the French nation gained 3.5 million square miles and 26 million people, a good portion of whom practised the Muslim faith and were to become the bulk of France's ethnic and religious minorities (Arendt, 1994: 124). Far-fetched as it may appear to American eyes (Arendt, 1959: 33), the colonial connection is essential for understanding the French approach to religion and its differences with America - for at least four reasons.

Firstly, colonialism, republicanism and laïcité were both historically and conceptually related in France. The French overseas expansion was encouraged by the Third Republic (1870-1940) and was thus strongly supported by the same politicians and opinion leaders who crafted the 1905 law. Secondly, the theoretical underpinnings of French colonialism rested upon the same secular and universal ideals of the Enlightenment and the French revolution that were so enthusiastically conveyed by the école laïque of the Third Republic and its civil religion. Thirdly, colonialism is understood to lie at the root of France's alleged difficulty in acknowledging diversity today, and it is often pointed to as the paramount example of - if not the very reason for-her assimilation tendencies (Renault and Touraine, 2005: 25). Fourthly and lastly, the French Empire played a crucial role in the immigration issue, as the migratory trends of the $20^{\text {th }}$ century inevitably attracted former colonial subjects to the motherland. I shall consider each of these four points separately.

\subsection{French Imperialism and the French Revolution}

A modern observer may find it difficult to connect the French Revolution with imperialism conceptually, for what is more opposed to liberté, egalité and fraternité than the two elements common to colonialism everywhere, that is to say, racism and (the actual or ever present threat of) violence? The uniquely 'French' foundational principle of equality provided the justification for the country's colonial enterprise in that equality needed to be spread across the world (Nicolet, 1994: 132). If the French Revolution was based upon worldwide values that transcended national territories and could be applied to all human beings, surely it was France's duty to teach them everywhere? So it is not surprising that the mission civilisatrice and its underlying tag of progress, equality and grandeur soon became the central dogma of colonial discourse. This idea was graphically conveyed by a delegate during a Human Rights League conference in Paris in 1931:

To teach science to the peoples who ignore it, to provide them with roads, canals, railways, cars, telegraphs, telephones, toilets, and to finally teach them the great message of human rights, this is a brotherly mission. The country that has proclaimed human rights, that has contributed to the advancement of science, that has created the laïque school, the country that more than any other is the champion of freedom, is bestowed with the mission of spreading far and wide the ideas that make it great. We should consider ourselves invested with the task of teaching, raising, emancipating, enriching and coming to the rescue of those peoples who need our help (Ageron, 1978: 70).

These were not the words of an extremist, for French colonialism did not grow out of extremism. Rather, it grew out of an extended interpretation of the revolutionary ideals of universality and human rights and it was based upon the assumption that, with the help of France, any 'savage' could indeed be 'cultured' (Girardet, 1990). "An uncivilized person is like a child" (Ruscio, 1995: 59), Victor Hugo used to say, implying that French education could instruct individuals in, and imbue them with, the values of France-it could, in a certain sense, turn the 'savage' not only into a French citizen but into a 'culturally' French person. The historian Jules Michelet understood this as early as in 1835 when he wrote, in his Introduction à l'Histoire Universelle, that

[w] hat the Frenchman wants to do most is to transfer his character to the vanquished, a character that he does not regard as his own but as embodying the archetype of Good. Such is his naïve 
conviction, and he truly believes he cannot do anything more profitable than giving his ideas, habits and way of life to the conquered (Ruscio, 1995: 94).

The 'uncivilized' were indeed able to learn and the task of bringing the revolutionary flame of reason to these people fell naturally upon the Frenchman.

\subsection{French Imperialism and Church-State Separation}

Perhaps because the events of 1905 occupy such a sacred place in the collective consciousness of the French, it is often forgotten that imperialism and Church-State separation are intimately connected in France. The secular Third Republic that passed the 1905 law and fought against the Catholic Church fully supported imperial expansion and gave a decisive impulse to the great military conquests of 1880 to 1910 (Bancel et al, 2004: 26). As Jean Jaurès, one of the Fathers of the separation, declared in Parliament (Ruscio, 1995: 92),

[w] hen we take control of a country, we have to carry with us the glory of France, and be assured that it will be welcomed everywhere, because such a glory is pure, great and filled with justice and righteousness.

The left-wing separation Fathers thus defended the virtues of colonialism and secularism with equal vigour. This was a logical consequence of their universal approach to human rights which were, the French Revolution had taught, valid anywhere, anytime, for everyone, and which France had a duty to export. As Aristide Briand, the architect of the 1905 law, told Parliament on the eve of the separation,

[t]here are some peoples who can live in freedom through a federal system, but who among themselves need a connection.... By building this connection for them, France provides them with the most important service they can wish for (Ruscio, 1995: 91).

The colonial enterprise perfectly dovetailed with the ideological system emerging from secular republican ideology, because from the start colonization - which was associated with the Republican values of progress, equality and grandeur - was constructed as a project that united all French people, social groups and political parties, and represented a powerful antidote to the divisiveness of the religious issue (Conklin, 1997).

In their quest for universality and support for colonialism, however, the French separation Fathers were doubly inconsistent. Although they truly wanted to be modernizing and universal, they simultaneously spoke of, and believed in, the existence of unequal races (Ezra, 2000). "We must have the courage to openly say that the superior races have a duty towards the inferior ones" (Ezra, 2000: 35), Jules Ferry-Prime Minister and the author of the secular education laws of the 1880s - told Parliament. Unsurprisingly, these men had a patronising mindset that was typical of the European Christian missionary of the time. As one author observed, "[a]t the same time as Europe was submitting and exploiting its colonies, the European proclaimed himself as the [God-mandated] protector, the educator, the tutor of these peoples who were trying to make up for their delay in the journey towards civilization" (Ruscio, 1995: 93).

\subsection{French Imperialism and Education}

Education was to play a crucial role in this formative mission of Imperial France. The secular education system of the Third Republic, reflecting as it did the egalitarian, unifying and universal aspirations of the école laïque, was regarded as ideally suited to serve both the developing needs of the 'savages' as well as the imperial urges of the motherland (Chanet, 1996). After all, the colonies represented an excellent chance for France to apply abroad what she was trying to realize at home: an ever-stronger state, the unity of all social strata and the reduction of racial as well as religious differences behind the same common project-republicanism — and a shared enthusiasm for the national and egalitarian ideals of the République. "Everything has been attempted in order to create "colonial citizens", one author stressed (Blanchard and Lemaire, 2004: 27).

The connection between the mission civilisatrice of France and her educational ideals was thus a powerful one, and the French Empire became an integral part of the civic religion taught in the nation's laïque schools as well as in her colonies. As Emile Combes said before the French Senate in 1892,

More than strength, the instruction of indigenous primary school kids ... will manage to effectively bridge the [civilization] gap and, by instilling in them [French] values, will teach them to regard themselves as members of the same human family, of the same Nation (Ruscio, 1995: 101).

This, however, did not mean that French children were taught equality. "The white race", a Third Republic school manual read, "[is the one] you belong to and [the one] you know very well" (Ruscio, 1995: 28). Yet teaching children to be part of the Empire contributed to the collective feeling of belonging to the Nation - to be 
colonial was, in this sense, to be French and it represented a necessary component of French national identity. "Colonial knowledge and education of the French people are an evident and pressing necessity", the French Colonial Minister declared, "and the propaganda in favour of our colonies is an essential component of our policy" (Blanchard and Lemaire, 2004: 50). Like individuals, nations need self-reassurance-especially if they are of a tender age like the République at the time-and the education system of Imperial France proved remarkably successful in this.

\subsection{French Imperialism and Assimilation}

Combine the universal human rights message of the French Revolution with the tendency towards homogeneity of the République and the unifying mission of French laïque schools, and the result can only be a strong assimilation policy. This was the paramount characteristic of French imperialism, at least before the later $20^{\text {th }}$ century brought with it increasing disenchantment amongst the populace. "A good law is good for every man", Condorcet wrote, and he was supported in this by Charles De Gaulle, an unlikey ally, for whom "[t]he best recipe for the complicated East are simple ideas" (Ruscio, 1995: 43).

Such ideas rested upon the belief that reason was the virtue of the world, that men were universally equal and that French laws could thus be applied anywhere. In other words, they rested upon strongly republican principles. "[L]iberty, equality, fraternity", one author observed, "the vocabulary relating to the doctrine of assimilation and that relating to these republican ideals were the same. These French ears attuned to republican phraseology also found familiar the phraseology in which the expansion of France overseas was justified" (Betts, 1991: 30). French colonies were thus to become an integral part of the motherland and their societies and populations were made in the image of France - because, as an Education Inspector wrote in 1890, "[w]e will never be the masters of Algeria until this country speaks French" (Ruscio, 1995: 101). That same year, the French National Colonial Congress passed a resolution proposing " $[\mathrm{t}]$ hat the efforts of colonization in all countries under French authority be directed in the sense of propagation among the natives of the language, habits and mind-set of the métropole" (Hanotaux, 1902: 365).

This was a fundamentally different approach from the one taken by Britain, the other great imperial power of the time. Instead of conquering and imposing their own laws upon their subjects, the British rejected the universalistic concept of the French doctrine and, in the words of a cynic Frenchman, "were never so foolish as to believe that the same system was suitable for all these peoples" (Betts, 1991: 45). The multifarious institutional structure of the United Kingdom never favoured outright assimilation of the colonized populations. Indeed, the British did not believe that their legislation was valid everywhere and consequently they supported local laws as long as they were in accordance with the interests of the British Empire. Thus, the British approach stood in stark contrast to the French policy, which aimed at incorporating overseas possessions into the national body by treating conquered people as "...both brothers and subjects - brothers in the fraternity of a common French civilization, and subjects in that they are disciples of French light and followers of French leading" (Barker, 1941: 4). The result, Hannah Arendt observed, was that "[c]ompared with this blind desperate [French] nationalism, British imperialists compromising on the mandate system looked like guardians of the self-determination of peoples" (Arendt, 1994: 129-30).

France was certainly not alone in rejecting local cultures in favour of the national identity, for imperialism is to some extent indissociable from assimilation. What sets the French colonial experience apart, however, is that France believed in assimilation so forcefully that she practised it "more consciously" than any other country (Betts, 1991: 168). The fact that such an assimilationist impulse coincided with the birth of the République-as well as with the psychological need to rally behind the nation and its fight against the Catholic Church - significantly contributed to the imperialism momentum and creed. And while the ideal principle of human equality was noble, the result was cultural imperialism and the rejection of local differences to the benefit of metropolitan France. Some observers still consider this contradiction to be at the heart of the country's forceful disdain for any form of multiculturalism à l'anglo-saxonne.

\subsection{French Imperialism and Immigration}

"The great difficulty of our [colonial] conquest", Emile Zola wrote in his Fecondité (1899), "[is] this terrible problem of Islam, a problem against which we will always clash until it is solved once and for all" (Ruscio, 1994: 119). When they began their colonial adventures, the French thought they had it all: a noble historical underpinning (the Revolution), a unifying ideology (republicanism), a simple methodology (assimilation), a sympathetic religion (Christianity), and the material and psychological support of an entire Nation.

In Asia, things worked out relatively well, for Confucianism and Buddhism were considered compatible with Christianity. However, in Northern Africa, France immediately clashed with Islam and Zola was not alone in 
emphasizing this confrontation. "[Islam] is the enemy of civilization", François-René De Chateaubriand wrote in his Génie du Christianisme, "[and it is] inherently a source of ignorance, despotism and slavery" (Ruscio, 1995: 113). Guy de Maupassant also expressed French colonial disappointment at the difficulty of assimilating Muslims: "These Arabs, whom we initially considered civilized, who were apparently inclined to accept our habits, share our ideas and support our actions, become all of a sudden, as soon as the Ramadan begins, savage fanatics and stupid extremists" (Ruscio, 1995: 114). The French colonists were, in other words, prepared for everything, except for the possibility that some 'subjects' would resist French culture (Hafiz and Devers, 2005: 77). How was this possible, given that it was bringing them the revolutionary freedoms? And that it was, after all, the best?

At the beginning of the $20^{\text {th }}$ century, when the migratory pendulum started to change and the former 'savages' travelled to France - first to fight in the First World War and then, encouraged by a manpower-hungry economy, to work and live there with their families - the Islam 'problem' so graphically identified by Zola, Chateaubriand and Maupassant demographically and figuratively moved from Africa to France. Today, the country's Muslim population constitutes an estimated $10 \%$ of the French population (about 5 million people), whereas the Muslim presence in America - which is unconnected to colonialism - is a mere 0,5\% (about 1.1 million).

Yet the experience of the French Empire suggests that this is not only a matter of numbers. If it is true that "the colonial spirit is the legitimate child of the refusal of diversity", as one author wrote (Ruscio, 1995: 12), then it is also correct to say that as a result of historical factors (the almost simultaneous birth of République and colonialism), theoretical principles (the universal humanism of the French Revolution) and practical objectives (the quest for domination), France established a system whereby local cultures and institutions were systematically rejected in favour of French ones.

Given this historical context, it is difficult to ignore the connection between France's colonial policy of assimilation and her current integration model. The latter is sceptical of, if not openly hostile to, any 'communalist' status offered on the basis of allegiance to a given group (religious or otherwise). As one French critic wrote,

"I]n France we confuse assimilation and uniformity. We are still with the old Platonic idea of universals. We want to model everyone in our own image, as if it had attained an absolute perfection, and as if all Frenchmen were alike" (Guyot, 1885: 215).

Far from being purely theoretical, this assimilationist propensity occasionally surfaces at the legal level as well: in 1991 the Conseil Constitutionnel ruled that the expression 'Corsican people' is "contrary to the French Constitution, which only knows of the French people, the latter being made up of all French citizens without distinction of origin, race or religion" (Conseil Constitutionnel, 1991). And in 1995 the Conseil d'État wrote that

"the idea of an ethnic minority is contrary to the concept of French people and to the principle of indivisibility of the Republic. This leads [us] to reject any category ther than that of 'French people', understood as the community of all French citizens" (Hafiz and Devers, 2005: 38).

While this policy might have successfully created national ties in the relatively uniform France of the $19^{\text {th }}$ century, it is bound to generate a number of problems in the increasingly multi-cultural and multi-religious France of the $21^{\text {st }}$ century. Indeed, the issue of the Muslim headscarf is arguably illustrative of these tensions (Renault and Touraine, 2005: 29).

\section{Conclusion: Religion in France and America Today}

The diverse politico-religious histories of France and the United States draw attention to one of the most daunting problems facing political leaders since the times of Sophocles: the need to balance belief and non-belief. In other words, these histories highlight the challenge inherent in the need for a democratic state to accommodate the rights of believers within the legal framework of a secular state. Despite the fact that France and America regard themselves as secular democracies and claim the moral high ground when it comes to individual rights and civil liberties, they have quite different - if not wholly contrasting - attitudes on how to achieve that goal.

This article has argued that the reason for this variance lies in the particular religious pasts of the two countries. European nation-states in general - and France in particular - have often seen religion as an obstacle (sometimes even a threat) to their own authority. The European Enlightenment ideas of a civic polity and a social contract did not require much commitment to a transcendental belief; indeed, they were arguably incompatible with it (Tilly, 1975: 42). European nation-states also disliked the significant temporal power still held by the Church, while the latter in turn often condemned the concentration of power and wealth in those states. The maxim Homo Proponit, Sed Deus Disponit ("Man proposes, but it is God who decides") may have been a popular dictum 
within clerical circles, but it hardly sat well with the newly-born European nation-states who were trying to increase their authority in a fragmented and conflict-torn world (Mastellaro, 1994: 96).

The US largely ignored the confrontational paradigm that has characterized Church-State relationships in Europe and France. Whereas the French revolutionaries thought that the State could only flourish when religion was out of the public realm (Burke, 1955: 33), the US Founding Fathers were convinced of the opposite, believing that religion was among the most powerful means of developing the self-governing morality required to maintain a free nation. Thus, in the New World religious feelings have been — and remain — so strong that they have become embedded in the nation's identity. Conversely in France, courtesy of the endless religious wars between the Church and State, there was - and partly still is - the widespread belief that égalité can only be achieved through laïcité. "No law, no [religious] practice is superior to that of the République, nor can or should become an obstacle to it”, France's Interior Minister (and later President) Nicolas Sarkozy pointed out (Le Monde, 2003).

Today the difference between France and America is arguably more nuanced because the balance of power between religion(s) and states has changed, as have the challenges faced by modern polities in regulating it. Contemporary multi-cultural and multi-religious societies in both Europe and the US face the challenge of having to accommodate, within one territory, the varied expectations of people belonging to different faiths as well as the rights of atheists. Yet one problem that all governments must tackle is the growing importance and the serious policy implications of religious matters in public affairs. The $21^{\text {st }}$ century is unlikely to change that.

\section{References}

Ageron, C. R. (1978). France Coloniale ou Parti Colonial. Paris: Presses Universitaires de France.

Agulhon, M. (1992). Républicain à la Française. Revue de Tocqueville, 13(1), 112.

Arendt, H. (1959). Reflections on Little Rock. Dissent, 6(1).

Arendt, H. (1994). The Origins of Totalitarianism. New York: Harcourt.

Autrand, F. (1974). Pouvoir et Société en France: XIVe-XVe siècles. Paris: Presses Universitaires de France.

Bailyn, B. (2003) .To Begin the World Anew. New York: Knopf.

Bancel, N., Blanchard, P., \& Lemaire, S. (2004). La Fracture Coloniale: Une Crise Française. In P. Blanchard \& S. Lemaire, Culture Impériale. Paris: Éditions Autrement.

Barker, E. (1941). Ideas and Ideals of the British Empire. Cambridge: Cambridge University Press.

Betts, R. (1991). France and Decolonization. London: Macmillan.

Blanchard, P., \& Lemaire, S. (2004). Culture Impériale. Paris: Éditions Autrement.

Brookings Center on the United States and Europe. (2004). The Veil Controversy. Washington, DC: Brookings.

Bruley, Y. (2004). La Séparation des Églises et de l'État: Les Textes Fondateurs. Paris: Perrin.

Burke, E. (1955). Reflections on the Revolution in France. Chicago: Regnery.

Chanet, J. F. (1996). L'École Républicaine et les Petites Patries. Paris: Aubier.

Charlier-Dagras, M. D. (2002). La Laïcité à l'Epreuve de l'Intégration Européenne. Paris: L'Harmattan.

Chélini-Pont, B. (2005). L'Héritage Culturel Français Face au Pluralisme Religieux. In Annuaire Droit et Religions. Aix-Marseille: PUAM.

Chélini-Pont, B., \& Gunn, T. J. (2005). Dieu en France et Aux États-Unis. Paris: Berg International.

Conklin, A. (1997). Mission to Civilize. Stanford: Stanford University Press.

Conseil Constitutionnel, DC n. 91.290 of 9 May 1991 («Statut de la Corse»).

Ezra, E. (2000). The Colonial Unconscious. Ithaca, NY: Cornell University Press.

Garay, A., Chélini Pont, B., Tawil E., \& Anseur, Z. (2005). The Permissible Scope of Legal Limitations on the Freedom of Religion or Belief in France. Emory International Law Review, 2, 821.

Girardet, R. (1990). L'Idée Coloniale en France de 1871 à 1962. Paris: Hachette.

Guyot, Y. (1885). Lettres sur la Politique Coloniale. Paris: Reinswald.

Hafiz, C., \& Devers, G. (2005). Droit et Religion Musulmane. Paris: Dalloz.

Hanotaux, G. (1902). L’Énergie Française. Paris: Flammarion.

Hugo, V. (1985). Euvres Complètes (Vol. 4). Paris: Laffont 
Hutson, J. H. (2002). Religion and the New Republic. Oxford: Rowman and Littlefield.

Le Monde. (2003, May 2). Vers une Nouvelle Citoyenneté Française.

Mastellaro, P. (1994). Il Libro delle Citazioni Latine e Greche. Milan: Mondadori.

McConnell, M. (1990). The Origins and Historical Understanding of Free Exercise of Religion. Harvard Law Review, 103, 1479. http://dx.doi.org/10.2307/1341281

Nicolet, C. (1994). L'Idée Républicaine de la France (1789-1924). Paris: Gallimard.

Ormières, J. L. (2002). Politique et Religion en France. Bruxelles: Éditions Complexe.

Peña-Ruiz, H. (2003). La Laïcité: Textes Choisis. Paris: Flammarion.

Quinet, E. (2001). L'Enseignement du Peuple. Paris: Hachette.

Rémond, R. (2000). Religion et Société en Europe: La Sécularisation aux XIXe et XXe Siècles. Paris: Seuil.

Renault, A., \& Touraine, A. (2005). Un Débat sur la Laïcité. Paris: Stock.

Ruscio, A. (1995). Le Crédo de l'Homme Blanc. Bruxelles: Complexe.

Safran, W. (2003). The Secular and the Sacred: Nation, Religion and Politics. London: Frank Cass.

Stout, H. S. (1998). Religion in American History: A Reader. Oxford: Oxford University Press.

The Economist. (2003, November 8). A Nation Apart: A Survey of America.

Tilly, C. (1975). The Formation of National Western States in Western Europe. Princeton: Princeton UP.

Tocqueville, A. (2003). Democracy in America and Two Essays on America. London: Penguin.

Voltaire. (1964). Lettres Philosophiques. Paris: Flammarion.

\section{Notes}

Note 1 . Similarly to France and well into the $18^{\text {th }}$ century, early America considered religion a useful policy instrument because, as one Massachusetts delegate declared, "[t]he fear and reverence of God, and the terrors of eternity, are the most powerful restraints upon the minds of men and hence it is of special importance in a free government...[that] it will hold up the Gospel as a great rule of faith and practice" (Hutson, 2002: 8). This article is a revised version of my Veiled Threats? Islam, Headscarves and Religious Freedom in America and France (AV, 2008). All translations are mine.

Note 2. In the United States there are over 2.000 denominations that identify as a religion, without taking into account the many independent churches and other faith-based communities.

Note 3. Voltaire would very much agree: "Two religions would get at each other's throat but, if there are thirty of them, they will leave each other in peace" (Voltaire, 1964: 47).

Note 4. "I swear to be faithful to the Nation, to the law and to the King", the pledge read, "and to uphold to the best of my abilities the Constitution decided by the National Assembly and accepted by the King". (Tackett, 1986, 35).

Note 5. "I swear and promise to God upon the Saint Evangels", the oath read, "to remain obedient and faithful to the government established by the Constitution of the French Republic. I also promise not to get involved, not to participate in any council, not to join any league, either internal or external, that is contrary to public tranquillity; and if, in my dioceses or elsewhere, I learn that something is being plotted against the State, I shall let the Government know" (Bruley, 2004: 48).

Note 6. There, as one author observed, "freedom of religion is a concept which is external to the intellectual and legal culture of [the country], whereas freedom of thought and rejection of religious belief are founding ones" (Chélini-Pont, 2005: 302).

Note 7. In light of this, it is unsurprising that surveys routinely find the United States to be one of the most religious societies of the Western world, while France is among those most detached from religion. A 2003 study, for example, reported that religion plays a very important role in the lives of $60 \%$ of US citizens in contrast to $10 \%$ of French citizens (The Economist, 2003).

Note 8. As Hannah Arendt wrote, “[a] great enthusiasm for 'new specimen of mankind' (Herder) filled the hearts of the heroes of the French Revolution who together with the French nation liberated every people of every colour under the French flag. This enthusiasm for strange and foreign countries culminated in the message of 
fraternity, because it was inspired by the desire to prove in every new and surprising 'specimen of mankind' the old saying of La Bruyère: 'Reason is the same everywhere"'. (Arendt, 1994: 161-2).

Note 9. Perhaps one reason was that, during the colonial time, the spirit of the Enlightenment and the French Revolution percolated to the 'savages' only in microscopic doses. French citizenship was, for example, refused to Algerian people of Muslim faith and only in 1947 was it possible for them to be French and Muslim — but still with the stigma of being registered as French Muslims. Algeria was French, in other words, but not French enough to grant French citizenship to her people. Even more peculiarly, the 1905 law of separation never applied to Algeria, so while the French state became secular in metropolitan France, it never became so in Algeria and religious freedom was limited by a local civil administration whose purpose was largely to keep Islam under control. Only in 1947 was the Muslim faith rendered independent from the State (Hafiz and Devers, 2005: 77). 